\title{
Troubled Relationships under the GATS: Tensions between Market Access (Article XVI), National Treatment (Article XVII), and Domestic Regulation (Article VI)
}

\author{
GILLES MULLER * \\ New York University School of Law
}

\begin{abstract}
The General Agreement on Trade in Services (GATS) was adopted in order to establish meaningful liberalization rules, while preserving the right of Members to regulate. To that end, three provisions form the centerpiece of liberalization: market access (Article XVI GATS), national treatment (Article XVII GATS), and domestic regulation (Article VI GATS). Although these provisions contain different obligations, in certain conditions they can overlap. How this issue is resolved could undermine the delicate balance between liberalization and the right to regulate. As the GATS provides no guidance, the task of determining the applicable rules has been delegated to the World Trade Organization (WTO) adjudicating bodies. This paper examines how the three provisions have been interpreted, and analyzes the most applicable way to address the diversity of barriers to trade in services.
\end{abstract}

\section{Introduction}

Since the advent of the General Agreement on Tariffs and Trade (GATT) in 1948, tariffs have fallen; consequently, attention has progressively shifted to other types of instruments such as non-tariff barriers (NTBs) and barriers to trade in services. This, in turn, has led to calls for greater attention to be given to internal regulations that constitute barriers to international trade, ${ }^{1}$ particularly trade in services.

Regulatory intervention in the services market is particularly important. In some instances, consumers cannot assess the quality of service, and regulation aims to prevent suppliers from abusing information asymmetry. It can also minimize negative externalities, where third parties (rather than suppliers or consumers) decide on the cost of supply of certain services. Regulation enables governments to ensure that services are equally available to all citizens. In some cases, it is used to further policy objectives (such as job creation or access to the labor market);

* Email: gilles.muller@law.nyu.edu.

1 World Trade Organization (2012). 
while in others, it aims to maintain order (by protecting the public from fraud, tax evasion, or anti-competitive practice). Finally, effective regulation in the liberalization of service sectors can help to achieve gains without compromising quality or other policy objectives.

At the same time, 'behind the border' measures can have a negative impact on international trade. Discriminatory regulations can favor domestic services and suppliers of services over their foreign equivalents. Measures can also take the form of origin neutral quantitative restrictions that both impede entry into the market, and protect incumbent suppliers from competition. Furthermore, trade in services can be affected by non-discriminatory domestic regulation that takes the form of cumbersome and/or opaque licensing and qualification procedures, non-transparent criteria, and excessively burdensome and redundant requirements. Similarly, multiple regulatory systems and standards increase compliance costs and are a barrier to trade. ${ }^{2}$

The General Agreement on Trade in Services (GATS) came into force in 1995. Its purpose was to establish a multilateral framework of principles and rules with a view to the expansion of trade in services under the conditions of progressive liberalization (GATS Preamble, Rec. 1). At the same time, it recognized the right of Members to regulate in order to meet national policy objectives (GATS Preamble, Rec. 3). The challenge therefore faced by the drafters of the Agreement was, on the one hand, to identify - among the wide range of internal regulations - measures that could be considered as trade restrictions and, on the other hand, to draw up liberalization rules that preserve the right of Members to regulate in order to meet their national policy objectives.

Three provisions were developed as the centerpieces of liberalization under the GATS. First, market access provisions (Article XVI GATS) list a series of (mostly quantitative) discriminatory or non-discriminatory measures that affect entry and establishment in the market and have a significant impact on market contestability. Second, national treatment (Article XVII GATS) concerns discriminatory measures that affect foreign services and service suppliers, and modify competition conditions in favor of domestic counterparts. Third, domestic regulation (Article VI GATS) ensures that non-discriminatory regulation serves legitimate policy objectives, and is not a form of protectionism. It also mitigates any unintended, traderestrictive consequences of national differences in regulatory requirements and the way they are administered.

On paper, the distinctions between market access provisions (Article XVI), national treatment (Article XVII), and domestic regulation measures (Article VI) appear straightforward. However, reality is more complex as the rules may overlap: a discriminatory quantitative restriction listed in Article XVI can also fall under the scope of Article XVII; a non-discriminatory quantitative restriction 
listed in Article XVI is also covered by Article VI; or a de facto or origin neutral discriminatory measure under Article XVII can also be considered as a domestic regulation under Article VI.

These overlaps could affect WTO Members' right to regulate, as Articles XVI, XVII, and VI contain different obligations. Market access and national treatment are aimed at the removal of measures covered by these provisions. Their violation can only be justified for a limited number of reasons that are listed in Article XIV GATS. In contrast, the purpose of domestic regulation is the mitigation (rather than the removal) of measures that have a negative impact on trade. A violation of this obligation can be justified for a non-exhaustive list of reasons. When there is an overlap, market access and national treatment rules have more potential than domestic regulation provisions to have an impact on the right of a WTO Member to regulate. For instance, a broad interpretation of the measures listed in Article XVI GATS could encroach on the scope of application of Article VI GATS, expose a wide range of WTO Members' internal regulations to an extensive test, and affect their regulatory autonomy.

The GATS does not provide clear rules to resolve situations where there is a conflict between two applicable provisions. As a result, this task has been delegated to WTO adjudicating bodies. Their decisions have provoked intense debate on the scope of these provisions and their impact on the delicate balance that the Agreement seeks to strike between the liberalization of trade in services on the one hand, and the preservation of the right to regulate in order to meet national policy objectives on the other.

This paper discusses the interactions between Articles XVI, XVII, and VI GATS. It aims to determine the regime that is applicable to both discriminatory measures and origin neutral measures that affect trade in services. It begins with an analysis of the relationship between market access provisions (Article XVI) and national treatment (Article XVII). Then, it deals with interactions between market access (Article XVI) and domestic regulation measures (Article VI). Finally, it addresses the relationship between national treatment (Article XVII) and domestic regulation (Article VI).

\section{Market access (Article XVI) - national treatment (Article XVII)}

\subsection{Articles XVI-XVII GATS in a nutshell}

Articles XVI and XVII are found in GATS Part III entitled 'Specific Commitments'. Commitments are specific because each Member may choose to what extent the obligations contained in these provisions are applicable to them.

Article XVI GATS lists prohibited discriminatory and non-discriminatory measures. More specifically, Article XVI:2 contains a list of measures that Members shall not maintain in sectors where full market access commitments are undertaken. This list includes four types of quantitative restrictions: (a) limitations on the 
number of service suppliers; (b) limitations on the total value of service transactions or assets; (c) limitations on the total number of service operations or on the total of quantity of service output; and (d) limitations on the total number of natural persons that may be employed or that a service supplier may employ. It also lists other restrictions, such as: measures that restrict or require specific types of legal entity or joint venture, and limitations on the participation of foreign capital.

Unlike Article XVI, Article XVII GATS does not set out a list of prohibited measures. Instead, it includes an obligation for Members to accord foreign services and service suppliers 'treatment no less favorable than it accords to its own like services and service suppliers'. Article XVII: 2 specifies that this obligation covers 'formally identical treatment or formally different treatment', i.e. de jure and de facto discrimination. Article XVII:3 specifies that a measure breaches national treatment obligations 'if it modifies the conditions of competition in favor of services and service suppliers of the Member compared to like services and service suppliers of any other Member'. Footnote 10 to the Article limits its scope: the national treatment obligation 'shall not be construed to require any Member to compensate for any inherent competitive disadvantages which result from the foreign character of the relevant services or service suppliers'.

These provisions are applicable under the condition that a Member undertakes specific commitments for each service sector. In so doing, they may choose the service sector and mode of supply ${ }^{3}$ they intend to liberalize, as well as the level of liberalization. Members wishing to liberalize a service sector must enter it, and the level of liberalization, in a so-called 'Schedule of Commitments' in the Market Access and National Treatment columns for each mode of supply. There are three alternatives when making specific commitments. The first is none. In this case, market access and national treatment requirements are fully applicable to the sector and mode of supply. The second is unbound. Here, commitments do not apply to particular modes of supply or subsectors. The third is to specify the exempted measures. This allows the Member to undertake a commitment, but limit it to specific circumstances or exempt particular measures, by providing a short description or summary of the regulation. ${ }^{4}$

3 Article I:2 GATS defines the four modes. Mode 1 (Article I:2(a)) covers the supply of a service 'from the territory of one Member into the territory of any other Member'. In this case, only the service crosses the border while service suppliers and consumers do not. Mode 2 (Article I:2(b)) is the supply of a service 'in the territory of one Member to the service consumer of any other Member'. Here, the consumer of the service goes to the country where the service is provided. Mode 3 (Article I:2(c)) deals with the supply of a service 'by a service supplier of one Member, through commercial presence in the territory of any other Member'. Here, the service provider establishes a firm in the territory of another Member in order to supply their services on a permanent basis. Finally, Mode 4 (Article I:2(d)) describes a service supplied 'by a service supplier of one Member, through presence of natural persons of a Member in the territory of any other Member'.

4 WTO-CTS (2001). 
To a certain extent, both Market Access and National Treatment address discriminatory measures: Article XVI:2 prohibits six types of discriminatory and non-discriminatory measures, while Article XVII requires non-discrimination between domestic and foreign services and service suppliers. Therefore, the same discriminatory measures listed in Article XVI may also fall within the scope of Article XVII.

This situation makes it difficult to interpret Members' commitments. For instance, it may become problematic to determine the level of liberalization when a Member registers a commitment unbound under market access and none under national treatment. Does this mean that it retains its power to discriminate regarding the measures listed in Article XVI (i.e. the inscription unbound prevails); or alternatively does this mean that it commits not to discriminate regarding both measures covered by Articles XVI and XVII (i.e. the inscription unbound prevails)? The GATS itself is no help, as it does not specify which provision prevails in the event of such an overlap.

The overlap also complicates the determination of the legal test that should be applied to a discriminatory measure. This is because Articles XVI and XVII contain distinctive sets of obligations, which have different consequences. Article XVI does not require an assessment of the discriminatory nature of the measure per se. It rather aims to determine whether there has been a violation of the commitment not to adopt or maintain quantitative restrictions. In this sense, Article XVI sets negative criteria: it prohibits the use of a set of measures that limit market access regardless of their discriminatory nature. In contrast, national treatment provides normative criteria that Members must follow when enacting regulations: they must accord foreign services and services suppliers 'treatment no less favorable' compared to 'like' domestic services and service suppliers. ${ }^{5}$ This allows Members to enact regulations as long as they are non-discriminatory. Therefore, the normative content of Article XVI is stricter and more demanding than that of Article XVII. ${ }^{6}$ Depending on the interpretation of the overlap, the non-discrimination obligation may become more demanding for Members.

\subsection{Articles XVI-XVII GATS: the overlap problem}

The overlap does not pose a major problem when a Member enters the same type of commitment (none, unbound, or specific limitation) in both market access and national treatment columns. In such an event, Article XX:2 states:

5 Panel Report, China-Measures Affecting Trading Rights and Distribution Services for Certain Publications and Audiovisual Entertainment Products, WT/DS363/R and Corr.1, adopted 19 January 2010 (China-Publications and Audiovisual Products), as modified by Appellate Body Report WT/ DS363/AB/R, paras. 7.1272, 7.942, and 7.956; Panel Report, China-Certain Measures Affecting Electronic Payment Services, WT/DS413, adopted 16 July 2012, paras. 7.641-7.643 (China-Electronic Payment Services).

6 Ortino (2006: 138-139). 
Measures inconsistent with both Articles XVI and XVII shall be inscribed in the column relating to Article XVI. In this case the inscription will be considered to provide a condition or qualification to Article XVII as well.

This Article therefore avoids the duplication of measures that are inconsistent with both market access and national treatment. A measure inscribed under Article XVI also functions as a limitation under Article XVII.

A problem does arise where different commitments are inscribed in the market access and national treatment columns. An example is if a Member enters unbound with respect to market access, and none regarding national treatment, leading to different interpretations. In this situation, the GATS does not provide a clear-cut solution.

This issue has sparked an intense debate among WTO Members sitting on the Committee on Specific Commitments (CSC). The Chairman of the Committee summarized the different positions into five approaches: ${ }^{7}$

- The first option would ensure the primacy of Article XVI: discriminatory measures listed under Article XVI:2 would fall exclusively within the scope of that Article and would be excluded from the scope of Article XVII. In such a situation, Article XVI would become the lex specialis of these measures.

- The second option would make it clear that the measures listed in Article XVI:2 only cover non-discriminatory measures. Any of these measures adopted in their discriminatory form would fall within the scope of Article XVII. Such an option would require the exclusion of measures referred to in Article XVI:2 subparagraphs (e) and (f), which could only be applied in a discriminatory form.

- The third option could be referred as 'the commitment unbound takes all': the commitment unbound under either the market access column or the national treatment column would permit a WTO Member to adopt a discriminatory measure falling within the overlap regardless of the entry in the other column. For instance, an unbound entry under in the market access column and none in the national treatment column would allow the Member to implement a measure covered by Article XVI even in its discriminatory form.

- The fourth option envisages the reverse situation and could be referred as 'the commitment none takes all': in the case of an overlap, the entry containing the commitment would prevail over an unbound entry. For instance, an entry none in the market access column and unbound in the national treatment column would outlaw any discriminatory measures falling within the scope of Article XVI.

- The fifth option would require the WTO Member to introduce clarifying text into their schedules regarding the intended scope of their commitments. Such an approach would oblige Members themselves to address the overlap issue. 
To date, there is no agreed solution, and consequently the task of determining the best approach has been left to WTO adjudicating bodies.

\subsection{The overlap problem after China-electronic payments services}

The problem of the overlap between Articles XVI and XVII obligations arose in China-Electronic Payments Services. It was a case in point: for the 'other financial services' sector China had inscribed unbound in mode 1 in the market access column, but had registered none in mode 1 in the national treatment column. This situation begged the question of which commitments were applicable to the discriminatory quantitative restrictions listed in Article XVI:2. If the Panel favored the primacy of Article XVI, China with its commitment of unbound in the market access column, could have retained its rights to maintain discriminatory measures under Article XVI. In contrast, if the Panel held that Article XVII covered all discriminatory measures, China, having made a commitment of none in the national treatment column, could be found in violation of its GATS obligations.

The Panel favored the primacy of Article XVI, as a lex specialis of Article XVII. Consequently, the inscription unbound in the market access column took precedence. This means that when a measure is inconsistent with both Articles XVI and XVII and unbound is inscribed in the market access column, the Member is not in breach of its full national treatment commitments as by market access limitations. ${ }^{8}$ In other words, the discriminatory measures listed in Article XVI:2 are analyzed in terms of Article XVI, while other discriminatory measures are assessed under Article XVII.

The Panel clarified that their intention was not to establish a hierarchy between these provisions, but rather to create a 'scheduling primacy' for entries in the market access column based on Article XX:2 GATS. ${ }^{9}$ In fact, the ruling indirectly delineated the scope of national treatment: discriminatory measures corresponding to the list of measures mentioned in Article XVI GATS fall outside the scope of Article XVII GATS.

Although the Appellate Body has not yet ruled on the matter, there are strong arguments in favor of this solution. First, Article XVI: 2 contains two sub-paragraphs ${ }^{10}$ covering specifically discriminatory situations. Therefore, limiting the subparagraphs of Article XVI:2 to non-discriminatory measures, as the second approach suggests, would require a contra legem interpretation of this provision, which goes beyond the mandate of the Dispute Settlement Understanding (Article 2.3 DSU). Second, this interpretation finds contextual support in Article $\mathrm{XX}: 2$ GATS. It is premised on the existence of measures 'inconsistent with both

8 Panel Report, China-Electronic Payment Services, paras. 7.649-7.664.

9 Ibid, para. 7.664 .

10 Article XVI:2 (e): ‘limitations on joint venture' and Article XVI:2 (f): 'limitations relating to foreign equity participation'. 
Article XVI and XVII', i.e. on the existence of measures within the scope of Article XVI:2 that appear discriminatory. ${ }^{11}$ This provision gives precedence to Article XVI GATS when identical commitments are found in market access and national treatment columns. Although it does not explicitly govern the situation where commitments are contradictory, it offers a legal context for the adoption of the most suitable interpretation. ${ }^{12}$ In contrast, the four other approaches lack textual support.

\subsection{Conclusion}

As a result, the Panel's interpretation appears reasonable; moreover, it has not been appealed. Therefore, it can be concluded that China-Electronic Payments Services offers a certain degree of clarification on the interpretation of specific commitments. It may oblige some Members to reconsider their schedules and clarify their level of liberalization. The Panel's report also indirectly provides some guidance on the relationship between Articles XVI and XVII and their respective scope. Article XVI has a central role with respect to discriminatory measures in the preestablishment stage. As a result, the non-discrimination requirement becomes more stringent.

At the same time, it raises a question regarding the scope of national treatment, depending on whether it covers the pre-establishment and/or post-establishment situation. If Article XVII is considered to only cover pre-establishment discrimination, then the scope of the national treatment obligation could be significantly limited. ${ }^{13}$ The GATS does not provide a clear answer to this question. In Argentina-Financial Services, both the parties and the Panel appeared to consider that national treatment only applies to pre-establishment. ${ }^{14}$ As the Appellate Body did not address the matter, the question remains open.

\section{Market access (Article XVI) - domestic regulation (Article VI)}

\subsection{Article VI GATS in a nutshell}

Article VI GATS is found in Part II 'General obligations and Disciplines'. Therefore, unlike Articles XVI and XVII, obligations under Article VI are general, i.e. they do not depend on specific commitments. These requirements are nevertheless conditional: their application is limited to service sectors where Members have undertaken liberalization commitments (Article VI:1, 3, and 5).

11 Panel Report, China-Electronic Payment Services, paras. 7.653-7.654.

12 Ibid, para. 7.659.

13 Mattoo (1997: 117).

14 Panel Report, Argentina-Measures Relating to Trade in Goods and Services, WT/DS453/R, 30 September 2015, paras. 7.107-7.113 (Argentina-Financial Services). 
Article VI contains two sets of obligations. First, it includes disciplines of a procedural nature related to the application (Article VI:3), administration (Article VI:1), and review (Article VI:2) of all measures of general application affecting trade in services. ${ }^{15}$ Second, Article VI:4-5 GATS contains substantive obligations related to qualification/licensing requirements and procedures and technical standards (hereinafter: QLT). Article VI:4 mandates the Council for Trade in Services, through appropriate bodies, to develop disciplines with a view to ensuring that QLT inter alia do not constitute unnecessary barriers to trade in services. Pending the entry into force of these disciplines, Article VI:5 requires WTO Members to adopt QLT that are based on objective and transparent criteria, and are not more burdensome than necessary to ensure the quality of the service (Article VI:5(a)) with the aim of not nullifying or affecting specific commitments made under Articles XVI and XVII GATS.

\subsection{Relationship between Articles XVI-VI GATS}

To a certain extent, some QLT can be understood as market access restrictions as it is quite clear that the scope of Article XVI extends to domestic regulation: most of the measures mentioned in Article XVI: 2 are market access restrictions applied in a domestic regulatory context. This situation could result in an overlap of the two provisions.

The GATS does not explicitly address the relationship between Article XVI and Article VI. On the basis of the Scheduling Guidelines ${ }^{16}$ (1993 Scheduling Guidelines $^{17}$ and the 2001 Scheduling Guidelines ${ }^{18}$ ), the Panel in US-Gambling declared that 'Article VI:4 and VI:5 on the one hand and Article XVI on the other hand are mutually exclusive'. ${ }^{19}$ The Appellate Body seemed to distance itself from this finding, refusing to draw a distinction in the abstract. ${ }^{20}$ Consequently, WTO case law does not provide a clear demarcation between Articles XVI and VI.

Nevertheless, some elements tend to support the primacy of Article XVI over Article VI. First, Article VI:5 states that a Member shall not apply QLT 'that nullify or impair the specific commitments made under Article XVI and XVII

15 Panel Report, United States - Measures Affecting the Cross-Border Supply of Gambling and Betting Services, WT/DS285/R, adopted 20 April 2005 (US-Gambling), as modified by Appellate Body Report WT/DS285/AB/R, DSR 2005:XII, p. 5797, para. 6.432.

16 The Scheduling Guidelines were adopted by the Council for Trade in Services in order to help Members negotiate their commitments. During the Uruguay Round, Members used the so-called 1993 Scheduling Guidelines. In the current round of negotiations they have been using the 2001 Scheduling Guidelines.

17 WTO-Secretariat (1993).

18 WTO-CTS (2001).

19 Panel Report, US-Gambling, para. 6.305.

20 Appellate Body Report, United States - Measures Affecting the Cross-Border Supply of Gambling and Betting Services, WT/DS285/AB/R, adopted 20 April 2005, para. 250 (US-Gambling). 
GATS', which tends to suggest that Article VI is complementary to Articles XVI and XVII. In addition, the most recent draft of the Working Party of Domestic Regulation (WPDR) mentions that the disciplines of Article VI:4 should not apply to measures to the extent that they constitute limitations subject to scheduling under Article XVI or XVII. ${ }^{21}$ Current negotiations reflect general agreement on this issue among Members. ${ }^{22}$

Accordingly, origin neutral restrictions found in Members' internal regulations, which affect trade in services, are first analyzed under Article XVI, then under Article VI. The purview of these provisions is different.

Article XVI covers quantitative restrictions - listed in Article XVI:2 (a-d)) which do not relate to the quality of the services supplied, or to the ability of the supplier to supply the service. They impose 'maximum limitations' that cannot be overcome by any action of the supplier. ${ }^{23}$ Measures such as: an economic need test for certain service suppliers; an annual quota for foreign service suppliers in a service sector; or a limitation on the number of employees foreign companies are allowed to hire fall into this category. These restrictions are considered most harmful, and can only be justified by a limited number of reasons that must be listed in Article XIV GATS. They thus have greater impact on WTO Members' regulatory autonomy. This situation is nonetheless rebalanced by the specific commitments mechanism.

In contrast, Article VI is concerned with qualitative domestic regulations related to the quality of services, or the ability of service suppliers. They impose a 'minimum limitation', i.e. requirements for the provision of services that service suppliers must fulfill in order to be authorized to supply their services. They can take different forms such as: educational requirements; minimum years of practice; proof of character; membership of a professional organization or the mandatory use of specific technical content.

\subsection{The interpretation of Article XVI GATS in US-Gambling}

A problem arises when the scope of the measures listed in Article XVI is extended, and encroaches on measures that should fall within the remit of Article VI. However, the two articles serve different purposes.

Article XVI prohibits certain measures and aims to remove them, although they can be justified on limited grounds that must be listed in Article XIV. In contrast, under Article VI:4-5, measures are presumed to serve a legitimate regulatory purpose. Obligations focus on ways to achieve the policy objective in order to mitigate any negative impact on the cross-border supply of services by increasing the transparency of domestic regulation or by ensuring that domestic regulation is 
not more trade restrictive than necessary to meet its stated objective. It follows that Article VI obligations leave more room for regulatory autonomy than Article XVI, which does not require the removal of the measure in question, but rather implies a discussion of other ways to achieve the stated regulatory objective. In this context, broadening the scope of Article XVI could limit Members' right to regulate.

This was the background for US-Gambling. The case involved a series of United States federal and state measures that restricted the remote supply of gambling and betting services to consumers within the country. Antigua claimed that such measures resulted in a 'total prohibition' of the cross-border supply of gambling services from Antigua that was in violation of United States' obligations under the GATS. First, it was established that the United States had inscribed none in the Market Access column in mode 1 for gambling and betting services, which meant that it had committed to not maintain any of the types of measures listed in the six subparagraphs of Article XVI:2. The subsequent question was whether the full prohibition of remote gambling services had breached Article XVI:2 GATS subparagraphs (a) and (c).

As mentioned earlier, Article XVI:2 contains a list of measures that Members shall not maintain or adopt in sectors where market access commitments are undertaken. This list includes mostly quantitative restrictions. In particular, paragraph (a) refers to the 'limitation on the number of services whether in the form of numerical quotas, monopolies, exclusive service suppliers or the requirements of an economic needs test'. In addition, paragraph (c) includes 'limitations on the total number of service operations or on the total quantity of service output expressed in terms of designated numerical units in the forms of quotas or the requirements of an economic needs test'.

The problem stems from the fact that the full prohibition of service suppliers and services, such as is found in United States' gambling laws, are not expressly mentioned in Article XVI:2 subparagraphs (a) and (c). This situation led WTO adjudicating bodies to be asked to interpret Article XVI GATS to determine whether this type of restriction could be read into subparagraphs (a) and (c). Both the Panel and the Appellate Body held that the list of measures in Article XVI:2 was exhaustive. ${ }^{24}$ In addition, the Panel found that the limitations enumerated in subparagraphs (a) and (c) were not illustrative, but exclusive. ${ }^{25}$ The Appellate Body indirectly confirmed this opinion, holding that the words 'in the form' found in Article XVI:2 (a) should not be replaced by the words 'that have the effect of'.26

Therefore, the specific question was whether a full prohibition could amount to a 'limitation on the number of suppliers' within the meaning of Article XVI:2(a) as well as a 'limitation on the total number of service operations' within the

24 Panel Report, US-Gambling, para. 6.318; Appellate Body Report, US-Gambling, para. 215.

25 Panel Report, US-Gambling, para. 6.325.

26 Appellate Body Report, US-Gambling, para. 232. 
meaning of Article XVI:2(c). Both the Panel and the Appellate Body held that a full prohibition of certain services effectively 'limited to zero' the number of service suppliers and service operations relating to that service. Such a prohibition amounts to a 'zero quota', which constitutes a limitation on both the number of suppliers (Article XVI:2(a)) and the number of service operations (Article XVI:2(c)).

\subsection{Relationship between Articles XVI-VI GATS after US-Gambling}

Some commentators criticized this interpretation on the grounds that it could extend the scope of Article XVI GATS to indirect quantitative restrictions that should normally fall within the purview of Article VI GATS. ${ }^{27}$ The risk is that the per se prohibition of market access (Article XVI) encroaches on the regulatory autonomy of WTO Members to set domestic regulations, undermining the delicate balance between trade liberalization and the right to regulate. To illustrate this point, Pauwelyn argued that indirect quantitative restrictions could include, for instance, the requirement for taxi drivers to pass a driving test, which would keep drivers that do not pass the test off the market. Obviously, such restrictions do not fall within the scope of Article XVI GATS, but his point was that the USGambling interpretation could result in this absurd situation. Instead, he suggested that United States' gambling law should be understood as a technical standard within the meaning of Article VI:4-5 GATS. ${ }^{28}$

Here, it is argued that the WTO adjudicating bodies' interpretation is more appropriate. Unlike most critics, it is submitted that a blanket prohibition on online gambling services cannot fall within the scope of Article VI GATS for the reasons outlined in the following paragraphs.

First, a total ban on online gambling services is more relevant to Article XVI. Article VI covers measures related to licensing/qualification requirements, and procedures and technical standards, which are designed to ensure the quality of service suppliers and services. They set minimum requirements that service suppliers must meet in order to be authorized to supply the service. A full prohibition can hardly serve to ensure the quality of a service as anticipated by Article VI, as no service suppliers can meet the requirement. ${ }^{29}$ In contrast, Article XVI addresses quantitative restrictions, found in domestic regulation, that limit cross-border services. It does not address the quality of the services supplied, or the ability of the supplier to supply the service, but rather imposes 'maximum limitations' that cannot be overcome by any action of the supplier. This is the situation of a total ban on online gambling services. 
Second, these restrictions do not amount to licensing/qualification requirements or procedures. A total ban on online gambling services leaves no room for an assessment of licensing or qualification requirements: it does nothing more than exclude the provision of the service. The situation would be different if regulations had been in place to limit the supply of such services to licensed providers, as this would fall under Article VI. This is not the case for a blanket prohibition as it prohibits supply in one mode.

Third, a total ban on online gambling services cannot be considered as a 'technical standard'. The GATS text does not define the term. Nevertheless, discussions amongst Members in the context of negotiations on the Disciplines on Domestic Regulation in the Accountancy Sector ${ }^{30}$ and other ongoing negotiations ${ }^{31}$ tend to suggest that 'technical standards' could be understood as criteria or rules specifying both the characteristics of the service, and the manner in which it should be performed. The distinction is somewhat akin to that made in the Technical Barriers to Trade (TBT) Agreement between 'product characteristics' and 'related processes and production methods' ${ }^{32}$ Therefore, the interpretation of a technical regulation developed under the TBT is relevant in the Article VI GATS context.

Three conditions must be met for a measure to be considered as a technical regulation. First, it must be a 'document' that 'lays down product/service characteristics'. Second, it must be mandatory. Third, it must be applicable to an identifiable product or group of products. ${ }^{33}$ While the two last conditions could be applicable to online gambling regulations, the central question is whether the regulations lay down product/service characteristics.

In EC-Seal Products, the Appellate Body noted that a measure that regulated the placement of seal products on the European market did not prescribe or impose any characteristics on the products themselves. ${ }^{34}$ However, in EC-Asbestos it held that despite appearances, a total ban on asbestos was a technical regulation as the measure effectively prescribed 'certain objective features, qualities or characteristics of all products', which must not contain asbestos fibers. It reached this conclusion only after a detailed examination of other aspects of the measure (i.e. certain exceptions to such a prohibition). ${ }^{35}$

In US-Gambling, the blanket prohibition regulated the placement of gambling services on United States' market without imposing or prescribing any characteristics on the service itself. Thus, the question is whether the measure effectively

30 WTO-CTS (1998).

31 WTO-WPDR (2009).

32 WTO -WPDR (2012b: 6-7).

33 Appellate Body Report, European Communities-Measures Affecting Asbestos and AsbestosContaining Products, WT/DS135/AB/R, adopted 5 April 2001, paras. 67-70 (EC-Asbestos).

34 Appellate Body Report, European Communities-Measures Probibiting the Importation and Marketing of Seal Products, WT/DS400/AB/R, WT/DS401/AB/R, 22 May 2014, para 5.58 (EC-Seal Products).

35 Appellate Body Report, EC-Asbestos, paras. 71-72 . 
prescribed 'certain objective features, qualities or characteristics of all products'. The prohibition of the supply of services in mode 1 could be understood a prescription of characteristics akin to the asbestos-free requirement. At the same time, the Appellate Body in EC-Asbestos specified 'the prohibition on asbestos fibres does not in itself prescribe or impose characteristics on asbestos fibres, but simply bans them in their natural state. Accordingly, if the measure consisted only of a prohibition on asbestos fibres, it might not constitute a technical regulation'. Certain states in the United States prohibit any form of gambling service, which, according to EC-Asbestos, implies that they do not constitute a technical standard. Furthermore, none of the relevant regulations related to online gambling provide for exceptions. As a result, and taken together, these elements suggest that a prohibition on online gambling services cannot be defined as a technical standard within the meaning of Article VI GATS.

In the light of these considerations, this paper submits that the Panel and the Appellate Body were correct in their interpretation that full prohibition constitutes a quantitative restriction within the meaning of Article XVI:2 GATS. It ultimately used Article XIV GATS exceptions relating to public morals and order to justify a violation of the Article. ${ }^{36}$

\subsection{Conclusion}

The foregoing shows that both Article XVI and Article VI address origin neutral domestic regulations that affect trade in services. Article XVI prohibits the use of a specific list of quantitative restrictions, while Article VI is concerned with measures related to the quality of services. Both provisions apply under the condition that Members have undertaken a commitment in the service sector: the application of Article XVI depends on the type of commitment, while Article VI refers to general conditional obligations. Article XVI takes precedence over Article VI.

A problem stems from the delimitation of the scope of Article XVI. In USGambling, both the Panel and the Appellate Body opted for a restrictive interpretation of Article XVI: they held that the measures listed in Article XVI were exhaustive, and specified that the subparagraphs were exclusive. Another issue arises with the interpretation of measures enumerated in the subparagraphs of Article XVI:2, which could extend their scope to measures that have an effect that is equivalent to those mentioned in subparagraphs $(\mathrm{a})$ to $(\mathrm{d})$.

The position taken here is that the Panel and the Appellate Body were correct in their interpretation, which qualified full prohibition as a quantitative restriction within the meaning of Article XVI:2 GATS. At the same time, it must be stressed that concerns about a broad interpretation of Article XVI GATS are legitimate, as it could affect WTO Members' regulatory autonomy. In this regard, the recent Argentina-Financial Services Panel report specified that any measure that 
only indirectly limits any of the elements covered by subparagraphs (a) to (d) would not be covered by Article XVI obligations. ${ }^{37}$ The Appellate Body has not addressed the issue.

\section{National treatment (Article XVII) - domestic regulation (Article VI)}

\subsection{Relationship between Articles XVI-VI GATS: origin neutral measures}

The national treatment obligation deals with discrimination between domestic and foreign services and service suppliers. A violation is established if four cumulative conditions are fulfilled: (i) the respondent has made a national treatment commitment in the relevant sector(s) or mode(s) of supply in its Schedule of Commitments; (ii) the measure 'affects' trade in services; (iii) domestic and foreign services and suppliers are 'like'; and (iv) the measure 'accords less favorable treatment' to foreign services and suppliers. ${ }^{38}$

The question of the relationship between Articles XVII and VI arises in relation to the interpretation of the 'no less favorable treatment' obligation. This question is the final step in establishing a violation of Article XVII. It includes de jure and de facto discriminatory measures (Article XVII:2). De jure discrimination openly links differences in treatment to the origin of services or service suppliers; de facto discrimination relates to differences in treatment that is not based on the origin of services and service suppliers, but from 'neutral' criteria. These measures are considered 'less favorable' when they modify the conditions of competition in favor of domestic services and suppliers compared to like services or service suppliers of another Member (Article XVII:3).

Therefore, both Article XVII and Article VI deal with origin neutral measures. Article XVII addresses any origin neutral measure (i.e. measures that do not discriminate overtly) that modifies conditions in favor of domestic services and suppliers; Article VI covers origin neutral measures related to licensing, qualification requirements and procedure and technical standards that are more trade restrictive than necessary to achieve legitimate regulatory objectives (Article VI:4-5).

The main difference between these provisions lies in their use of the necessity test. ${ }^{39}$ Under Article XVII, the test is used as an exception found in Article XIV. This provision provides WTO Members with a lawful escape route from their obligations: discriminatory measures can be maintained as long as such measures are

37 Panel Report, Argentina-Financial Services, paras. 7.420-7421.

38 Panel Report, China-Publications and Audiovisual Products, para. 7.944; Panel Report, ChinaElectronic Payment Services, para. 7.641; Panel Report, Argentina-Financial Services, para. 7.448.

39 In general terms, the test seeks to establish whether a measure can be justified based on whether it is necessary to achieve policy objectives. It reflects the balance that the WTO agreements seek to strike between two important goals: preserving the freedom of WTO Members to set and achieve their regulatory objectives through measures of their own choosing, on the one hand; and discouraging Members from adopting or maintaining measures that unduly restrict trade, on the other. WTO-WPDR (2003). 
proven to be necessary to achieve a regulatory objective. It includes an exhaustive list of policy purposes that justify derogation to trade liberalization. Under Article VI, the necessity test functions as an obligation. It applies directly to the measure at issue and seeks to ensure that such measures are not more restrictive than necessary to achieve a national policy objective. In this case, the list of permissible policy objectives is open.

The major difference between these two tests lies in the list of policy objectives that justify a derogation. Article XIV contains a closed list of policy objectives, while under Article the list is open. Hence, a measure that is not based on one of these objectives cannot be justified under Article XIV. Yet this list does not correspond to the reality of regulatory activities in the service sector, and the Appellate Body does not appear ready to transform the closed list into an open one. ${ }^{40}$

As a result, the justification of origin neutral measures that fall within the scope of Article XVII is more limited than those falling within the purview of Article VI. Extending the scope of Article XVII compared to Article VI could potentially severely affect Members' regulatory autonomy.

\subsection{The dividing line between Articles XVII-VI GATS: a definition of de facto discrimination}

It was noted above that Article VI GATS complements Articles XVI and XVII:specifically, it is applicable to measures that are not covered by Articles XVI and XVII obligations. Therefore, the interaction between Articles VII and VI depends on the definition of the scope of Article XVII, and more particularly the scope of the prohibition on de facto discrimination.

This issue is controversial as the only criterion mentioned in the GATS (Article XVII:3) is the 'modification of the conditions of competition in favor of domestic services and service suppliers compared to like services or service suppliers of any other Member', which could include a wide range of measures. Footnote 10 to Article XVII sets another limit: the national treatment obligation does not address 'any inherent competitive disadvantages, which result from the foreign character of the relevant services or service suppliers'. In other words, discrimination only arises if the disadvantage is caused by a Member's conduct in the form of a regulation or practice. ${ }^{41}$ Beyond this, there is no clear definition of the limits of de facto discrimination. ${ }^{42}$

Scholars have debated the issue. Various mechanisms have been suggested that either limit the scope of the prohibition of de facto discrimination, or include an

40 Appellate Body Report, EC-Seal Products, para. 5.118. The Appellate Body's interpretation concerned Article XX GATT, which is equivalent to Article XIV GATS.

41 Appellate Body Report, Argentina-Measures Relating to Trade in Goods and Services, WT/ DS453/AB/R, 14 April 2016, para. 6.104 (Argentina-Financial Services).

42 Krajewski and Engelke (2008: 412-416). 
assessment of regulatory purpose in the less favorable treatment assessment. Mattoo and Verhoosel propose the inclusion of a 'necessity test' in the less favorable treatment analysis. ${ }^{43}$ Zdouc puts forward a theoretical test to compare the restrictive impact of a measure on foreign services and service suppliers with the inherent competitive disadvantages resulting from the foreign character of the services. ${ }^{44}$ Krajewski suggests taking into account de facto discrimination that was foreseeable by Members at the time of scheduling. ${ }^{45}$ Cossy and Pauwelyn argue for the introduction of an improved aims and effects test. ${ }^{46}$ Diebold submits that competition is at the heart of the analysis and supports the application of an asymmetric impact test. ${ }^{47}$ Finally, Flett (following US-Clove Cigarettes) recommends excluding any measure that stems from the legitimate regulatory distinction in the analysis. ${ }^{48}$

More recently, the Appellate Body took the opportunity to provide its interpretation of the 'no less favorable treatment' in Argentina-Financial Services.

\subsection{Interpretation of 'No Less Favorable Treatment' in Argentina-financial services}

The case involved a series of measures adopted by the Argentine government, which set out different tax regimes for services and service suppliers in two jurisdictions: 'non-cooperative' and 'cooperative' ${ }^{49}$ Based on this distinction, Argentina put in place eight measures that affected cross-border trade in financial services between Argentine customers and taxpayers and Panamanian financial service suppliers (Panama being a 'non-cooperative' jurisdiction). In 2013, Panama brought a case against Argentina arguing that this distinction contravened non-discrimination obligations under the GATS.

The Panel found that most of these regulations were discriminatory within the meaning of Articles II and XVII. However, when interpreting the term 'no less favorable', it held that the reference to 'service suppliers' in Articles II and XVII might lead the interpreter to take into account 'the relevant regulatory aspects concerning service suppliers which have an impact on the condition of competition'. On this basis, it concluded that 'consideration of these regulatory aspects could ... mean that certain regulatory distinctions between service suppliers established by a Member do not necessarily constitute less favorable treatment under

43 Mattoo (1997: 129-133); Verhoosel (2002: 74-106).

44 Zdouc (2004: 412).

45 Krajewski (2003: 113-114).

46 Cossy (2008: 341-353); Pauwelyn (2008: 358-370).

47 Diebold (2010: 352-354).

48 Flett (2014: 55-91).

49 'Non-cooperative jurisdictions' do not exchange information with Argentina for purposes of tax transparency, the prevention of money laundering and terrorist financing. 'Cooperative jurisdictions' have agreements in place for the effective exchange of information, or fulfill certain requirements for starting negotiations on the issue. 
Articles II and XVII of the GATS'. ${ }^{50}$ Consequently, some measures that had originally been found discriminatory within the meaning of Article XVII were deemed consistent, as a result of their regulatory objectives.

Argentina appealed the decision, and the Appellate Body undertook a thorough analysis in order to determine whether the 'no less favorable treatment' requirement took into account the regulatory aspect of a measure. It began with an analysis of the GATS text, then examined the context for non-discriminatory provisions under the GATT and the TBT Agreement.

\section{The Text of the GATS}

The Panel considered that the definition of the 'no less favorable treatment' requirement was based on Article XVII:3 GATS related to the conditions of competition. In addition, it found that three elements in particular provided support for the inclusion of an assessment of the regulatory aspects of a measure: the broad scope of the GATS; 51 the reference to 'services and services suppliers'; 52 and the recognition (in the Preamble's third and fourth recitals) of Members' right to regulate in order to meet their national policy objectives. ${ }^{53}$

The Appellate Body argued that it did not see how the requirements regarding the conditions of competition could be modified by the introduction of considerations related to the regulatory aspects of a measure. First, it pointed out that the broad scope of application of GATS Articles II or XVII is not unique. Article III:4 GATT has also extensive scope, which has not justified the inclusion of regulatory aspects in the no less favorable treatment analysis. Second, it noted that the reference to 'service suppliers' is a particular feature of the GATS, but did not see how this reference could change the legal standard of 'treatment no less favorable', pointing out Panel's failure to provide satisfactory arguments. ${ }^{54}$ Third, it observed that the 'national policy objectives' referred to in the Preamble mean that Members who comply with their GATS commitments and obligations are free to pursue the national policy objectives that they consider appropriate. It stressed that the pursuit of these objectives was not equivalent to a violation of Members' GATS obligations and could be accommodated without the need to invoke Article XIV. Under certain conditions, exceptions can be used to recognize a Member's right to pursue objectives that are otherwise inconsistent with the GATS. This suggests a narrow scope, and consequently limited grounds for justification. ${ }^{55}$

These considerations led the Appellate Body to conclude that the interpretation of the term 'treatment no less favorable', which is based on a measure's detrimental

50 Panel Report, Argentina-Financial Services, para. 7.232.

51 Panel Report, Argentina-Financial Services, para. 7.232.

52 Ibid, para. 7.212.

53 Ibid, para. 7.217.

54 Appellate Body Report, Argentina-Financial Services, paras 6.108-6.111.

55 Ibid, para. 6.117. 
impact on the conditions of competition, does not prevent a Member from pursuing a wide range of national policy objectives that are beyond those identified in exceptions. ${ }^{56}$ It stressed that the GATS' structure provides two mechanisms that enable Members to preserve their right to pursue national policy objectives. First, they can utilize certain flexibilities when undertaking specific commitments (Article XX GATS). Second, Article XIV sets out general exceptions from their obligations. ${ }^{57}$

\section{The context of non-discriminatory provisions in the GATT and the TBT Agreement}

Another line of argument aimed to transpose the interpretation of national treatment under the TBT Agreement to GATS national treatment. This implies interpreting the scope of de facto discrimination under Article XVII GATS in the light of US-Clove Cigarettes. ${ }^{58}$

In this report, the Appellate Body held that the 'treatment no less favorable' requirement of Article 2.1 TBT should be interpreted as prohibiting only de jure and de facto discrimination against the group of imported products. In contrast, a detrimental impact on imports that 'stems exclusively from a legitimate regulatory distinction' fell outside its purview. ${ }^{59}$ In other words, the aim is to prohibit origin neutral measures that discriminate de facto against foreign products, but a measure that affects trade in services can be allowed if it stems exclusively from a legitimate regulatory distinction.

Transposed to the GATS, this would mean that once a panel finds that an origin neutral measure modifies the condition of competition in favor of domestic services and service suppliers, it must then determine whether such a measure stems exclusively from a legitimate regulatory distinction.

Support for this solution is based on the argument that the contents of Article XVII GATS and Article 2.1 TBT are comparable: they both require WTO Members to accord 'treatment no less favorable' to foreign products or services than to domestic counterparts. Furthermore, both Agreements have the same objectives in their Preambles: to strike the balance between trade liberalization and preservation of the rights of WTO Members. 60

However, the reasons for this interpretation are specific to the TBT: there are no exceptions in the TBT that are similar to Article XIV GATS. This was one of the main factors that led both the Panel ${ }^{61}$ and the Appellate Body ${ }^{62}$ in

56 Ibid, para. 6.118.

57 Ibid, paras. 6.112-6.115.

58 Panel Report, Argentina submission, Argentina-Financial Services, paras. 7.200-7.201. See also Flett (2014: 55-91).

59 Appellate Body Report, United States-Measures Affecting the Production and Sale of Clove

Cigarettes, WT/DS406/AB/R, adopted 24 April 2012, para. 181 (US-Clove Cigarettes).

60 Panel Report, Argentina-Financial Services, para. 7.200.

61 Ibid, paras. 7.229-7.231.

62 Appellate Body Report, Argentina-Financial Services, para. 6.121. 
Argentina-Financial Services to reject the incorporation of the US-Clove Cigarettes interpretation in the Article XVII GATS context. Furthermore, the Appellate Body stressed that the position was in line with its interpretation of national treatment under the GATT (Article III:4) in EC-Seal Products. ${ }^{63}$

\subsection{Relationship between Articles XVII and VI after Argentina-Financial Services}

As a result, the Appellate Body clearly ruled out any inclusion of an assessment of the regulatory purpose of a measure in the no less favorable treatment requirement. This interpretation is consistent with the Appellate Body's interpretation of national treatment under GATT.

This means that the only factor to be taken into account in the assessment is whether the measure in question modifies the conditions of competition in favor of domestic suppliers compared to their foreign counterparts, as long as this modification does not result from the foreign character of the relevant services or service suppliers (Footnote 10 of Article XVII). In their interpretation of the requirement, the Appellate Body limited the scope of the non-discrimination obligation. In ECBananas III, it adopted the 'asymmetric impact test' (which compares aggregated domestic sub-groups with their foreign equivalents) rather than the 'diagonal test' (which asks whether imports receive less favorable treatment than domestic products). ${ }^{64}$ The asymmetry test is more demanding than the diagonal test, as it is not sufficient to show that certain imported products receive less favorable treatment than certain domestic products. Instead, it is necessary to demonstrate that the regulatory burden negatively affects most imports compared to most (like) domestic products. ${ }^{65}$

There is no further guidance on the limits of de facto discrimination, making it difficult to assess the scope of a commitment none under national treatment. This raises the question of whether it only includes the most significant restrictions (such as residency requirements) for foreign services, or whether it also encompasses any restrictions to trade - similar to the Court of Justice of the European Union's interpretation in Säger ${ }^{66}$ and Gebhard, ${ }^{67}$ which prohibits any restrictions on trade in services unless they are considered necessary to protect the overriding public interest.

63 Appellate Body Report, EC-Seal Products, paras 5.100-5.117.

64 Appellate Body Report, European Communities-Regime for the Importation, Sale and Distribution of Bananas, WT/DS27/AB/R, adopted 25 September 1997, paras. 243-244, 246 (ECBananas III).

65 Ehring (2002).

66 In modes 1, 2, and 4, Säger C-76/90, Manfred Säger v. Dennemeyer \& Co. Ltd [1991], ECR I-4221.

67 In mode 3, Gebhard, C-55/94, Reinhard Gebhard v. Consiglio dell'Ordine degli Avvocati e Procuratori di Milano [1995], ECR I-4165. 
In Argentina-Financial Services, the Appellate Body stressed that the GATS' structure preserved Members' rights to regulate through two mechanisms: exceptions (Article XIV) and specific commitments (Article XX). In particular, it recalled that the specific commitments procedure enabled Members to use certain flexibilities in order to determine which sector market access and national treatment obligations applied to, and to what extent. ${ }^{68}$ Members are able to register their level of liberalization in a document referred to as the 'Schedule of Commitments'. Decisions are the result of successive rounds of market access negotiations (Article XX GATS) that are designed to increase the number of Members that make specific commitments in a maximum number of service sectors. WTO exporters submit requests to potential importers, stating the level of liberalization they are seeking in each service sector.

The negotiating process tends to be overlooked, but it is fundamental in the determination of national treatment. A broad interpretation of less favorable treatment that goes well beyond what has been negotiated could completely undermine the GATS process: Members that have agreed on the terms of liberalization after tough negotiations could find themselves trapped in unanticipated disputes, and be reluctant to make further commitments; other Members that have not yet undertaken commitments might be deterred from doing so. Such a situation would clearly be inconsistent with the principle of 'progressively higher levels of liberalization ... through successive rounds of multilateral negotiations' set out in the Second Recital of the GATS Preamble. It is thus crucial to understand how Members themselves see the scope of de facto discrimination, and then determine what this implies for its definition under Article XVII GATS.

In practice, Members' understanding of the scope of de facto discrimination appears to be quite narrow and focused on residency requirements in service sectors. Coupled with de jure discrimination, this narrow understanding is consistent with the limited number of exceptions in Article XIV GATS. It also leaves greater scope for the meaningful application of the necessity test as an obligation, and thus respects the balance between liberalization and the preservation of regulatory autonomy. However, a major problem is that Article VI GATS remains a work in progress.

\subsection{Article VI:4-5: the necessity test}

The necessity test is mentioned in two paragraphs of Article VI GATS:4 and 5. Article VI:5 GATS provides for the application of a necessity test to measures relating to licensing/qualification requirements and procedures, and technical standards, pending the entry into force of further disciplines. Article VI:5 GATS requires that WTO Members 'shall not apply licensing and qualification requirements and technical standards that nullify or impair such specific commitments 
in a manner which' [does not comply with the requirement to be] 'not more burdensome than necessary to ensure the quality of the service' (in service sectors where they have undertaken commitments). However, Article VI:5 (a) (ii) GATS limits the scope of this obligation to cases that 'could not reasonably have been expected of that Member at the time the specific commitments in those sectors were made'.

Article VI:4 GATS mandates the Council for Trade in Services to establish bodies to develop the necessary disciplines on measures relating to licensing/qualification requirements and procedures, and technical standards in order to ensure that they are inter alia: "not more burdensome than necessary to ensure the quality of the service'. Within the Working Party on Domestic Regulation (WPDR), WTO Members are currently negotiating the terms of these disciplines, which will apply to all service sectors.

The incorporation of the necessity test in future domestic regulation disciplines is a hotly debated issue. Some WTO Members are strongly opposed to the solution. ${ }^{69}$ As a result, WPDR negotiations have not provided any meaningful decisions. At the same time, the issue is a subject of negotiations regarding the Trade in Services Agreement (TISA) and Transatlantic Trade and Investment Partnership (TTIP). It remains to be seen whether these negotiators will finish the job. ${ }^{70}$

\subsection{Conclusion}

The foregoing shows that the relationship between Article XVII and Article VI concerns origin neutral measures. One of the main differences between the provisions is their use of the necessity test. Under Article XVII the test has a more limited scope than under Article VI, which could result in more limited regulatory autonomy for Members.

Even if the GATS does not expressly govern this relationship, there are strong arguments that favor the precedence of Article XVII over Article VI. Therefore, the delimitation between Article XVII and VI depends on the definition of the scope of de facto discrimination.

The issue has been hotly debated in the literature. In Argentina-Financial Services, the Appellate Body clearly ruled out any inclusion of the regulatory purpose of a measure in the less favorable treatment analysis. Yet, the exact scope of the prohibition of de facto discrimination remains unclear.

Based on the structure of the GATS and the current round of negotiations, this article argues that the scope should be narrow. This would result in the necessity test playing a significant role in Article VI. However, a meaningful test has not yet been developed due to resistance from Members in various arenas, be it the GATS, the TISA, or the TTIP. At the same time, barriers to trade in services, in 
the form of quantitative restrictions or overt discrimination, are being significantly reduced, while origin neutral limitations remain important. ${ }^{71}$ These evolutions beg the question of which regime should be applied to such restrictions: an inadequate national treatment obligation or an underdeveloped necessity test?

\section{Conclusion}

Articles XVI, XVII, and VI are the core provisions for liberalization under the GATS. Although each Article contains different obligations with different scope, in some cases they can overlap. This situation creates uncertainty with respect to both the scope of individual provisions and the balance between liberalization and the right of WTO Members to regulate. This paper analyzed the relationship between these provisions in order to determine the regime that is most applicable to discriminatory and origin neutral measures that affect trade in services.

The relationship between Article XVI GATS and Article XVII GATS influences the scope of the non-discrimination requirement under the GATS: the same discriminatory measure may fall within the scope of both provisions, raising the question of which provision is applicable. The Panel in China-Electronic Payments Services held that in the event of an overlap or contradictory specific commitments, the market access column prevailed over national treatment, making Article XVI a kind of lex specialis of Article XVII. This distinction has consequences for the scope of the non-discrimination requirement under the GATS, as Article XVI is stricter and more demanding than Article XVII. The non-discrimination obligation can become more intrusive, depending on the extent of the overlap, which is determined by the scope of measures listed in Article XVI. Beyond this list, discriminatory measures fall within the scope of Article XVII. In US-Gambling, WTO adjudicating bodies held that the Article XVI list is exhaustive and exclusive, thereby avoiding a broad, intrusive, non-discrimination obligation.

The interaction between Article VI and Article XVI, on the one hand, and Article VI and Article XVII, on the other hand, influence the fate of origin neutral measures that may fall within the scope of either. While the GATS itself is silent on this issue, events have supported the precedence of Articles XVI and XVII over Article VI. Therefore, the scope of Article VI is determined by the remit of Articles XVI and XVII.

With respect to Article XVI, US-Gambling found that the measures listed in Article XVI:2 are exhaustive and that its subparagraphs are exclusive. At the same time, the judges ruled that a total ban on online gambling services could amount to a 'zero quota' within the meaning of a 'numerical quota' (Article XVI:2 (a) and (c)). This interpretation raised the question of whether the list of measures in Article XVI:2 could include indirect quantitative restrictions. Such an 
interpretation could lead to an extension of the scope of Article XVI and hence encroach on the purview of Article VI. More importantly, it could seriously affect WTO Members' regulatory autonomy. More recently, the Panel in Argentina-Financial Services, made it clear that the remit of Article XVI does not extend to indirect quantitative restrictions. Like many other commentators, this paper welcomes this interpretation, which is more consistent with finding a balance between trade liberalization and the preservation of the right to regulate.

With respect to Article XVII, the question of the scope of the prohibition of de facto discrimination remains unclear. According to the text of the GATS, it includes any origin neutral measure that modifies the conditions of competition in favor of domestic services and service suppliers compared to their foreign counterparts. This could include a wide range of measures, as any measure affecting trade in services may have the effect of modifying the conditions of competition. Moreover, the mere existence of cross-border regulatory diversity represents a burden for foreign service suppliers. Various proposals have been put forward that aim to integrate the assessment of the regulatory objective in the less favorable treatment analysis. In Argentina-Financial Services, the Appellate Body clearly ruled out any inclusion of regulatory purpose in the less favorable treatment analysis, but did not indicate the exact scope of the prohibition of de facto discrimination. As a result, the scope of Article XVII (and incidentally the delimitation between Articles XVII and VI) remains unclear. However, taking a modification to the conditions of competition as the unique criteria could extend the scope of Article XVII and potentially encroach on WTO Members' regulatory autonomy. Here, it is submitted that the scope should be narrow, which would result in the necessity test playing a significant role in Article VI. However, a meaningful test remains to be developed as some Members have expressed strong opposition to its adoption in various arenas.

Under the current regime, Members' obligations regarding discriminatory measures are clear. In contrast, obligations related to origin neutral measures affecting trade in services are not. The issue is becoming increasingly important as barriers to trade in services are less discriminatory than origin neutral measures. ${ }^{72}$ Progress will require a refinement of the scope of Articles XVI and VII. At the same time, it will demand the development of meaningful domestic regulation obligations (Article VI). ${ }^{73}$ While negotiations on the development of effective transparency obligations appear to be well underway, the adoption of a consistent necessity test remains at a crossroads. ${ }^{74}$ 


\section{References}

Cossy, M. (2008), 'Some Thoughts on The Concepts of "Likeness" in the GATS', M. Panizzon, N. Pohl, and P. Sauvé (eds.), GATS and the Regulation of International Trade in Services, Cambridge: Cambridge University Press.

Delimatsis, P. (2006), 'Don't Gamble with GATS - The Interaction between Article VI, XVI, XVII and XVIII in the Light of the US-Gambling Case', Journal of World Trade, 40(6): 1059-1080.

Diebold, N. (2010), Non-Discrimination in International Trade in Services, "Likeness" in WTO/GATS, 2010, Cambridge: Cambridge University Press.

Ehring, L. (2002), 'De Facto Discrimination in World Trade Law, National Treatment and MostFavoured-Nation Treatment-or Equal Treatment?', Journal of World Trade, 36(5): 921-977.

Flett, J. (2014), 'National Treatment under the General Agreement on Trade in Services', in Anselm Kamperman Sander (ed.), The Principle of National Treatment: Trade, Investment and Intellectual Property, Cheltenham: Edward Edgar.

Krajewski, M. (2003), National Regulation and Trade Liberalization in Services: The Legal Impact of the General Agreement on Trade in Services (GATS) on National Regulatory Autonomy, The Hague, London, and New York: Kluwer Law International.

- (2005), 'Playing by the Rules of the Game?', Legal Issues of Economic Integration, 32(4): 417-447.

Krajewski, M. and E. Maika (2008). 'Article XVII GATS National Treatment', R. Wolfrum, P. T. Stoll, and C. Feinäugle (eds.), WTO-Trade in Services, Netherlands: Koninkljke Brill NV, pp. 396-420.

Mattoo, A. (1997), 'National Treatment in the GATS, Corner-Stone or Pandora's Box', Journal of World Trade, 31(1): 107-135.

Muller, G. (2015), 'The Necessity Test and Trade in Services: Unfinished Business?', Journal of World Trade, 49(6): 951-973.

Ortino, F. (2006), 'Treaty Interpretation and the WTO Appellate Body Report in US-Gambling: A Critique', Journal of International Economic Law, 9(1): 117-148.

Pauwelyn, J. (2005) 'Rien ne va plus? Distinguishing Domestic Regulation from Market Access in GATT and GATS', World Trade Review, 4(2): 131-170.

(2008), 'The Unbearable Lightness of Likeness', M. Panizzon, N. Pohl, and P. Sauvé (eds.), GATS and the Regulation of International Trade in Services, Cambridge: Cambridge University Press.

Verhoosel, G. (2002), National Treatment and WTO Dispute Settlement: Adjudicating the Boundaries of Regulatory Autonomy, Oxford: Hart Publishing.

Vranes, E. (2009), 'The WTO and Regulatory Freedom: WTO Disciplines on Market Access, NonDiscrimination and Domestic Regulation Relating to Trade in Goods and Services', Journal of International Economic Law, 12(4): 953-987.

World Trade Organization (WTO) (2012), Trade and Public Policies: A Closer Look at Non-Tariff Measures in the 21st Century, World Trade Report, Geneva: WTO.

— (2003), 'Considerations of Issues Relating to Article XX:2 of the GATS', Note by the Chairman, Committee on Specific Commitments, JOB(03)/213, 20 November 2003.

(1998), 'Decision on Disciplines Relating to the Accountancy Sector', The Council for Trade in Services, S/L/63, 14 December 1998.

(2001), 'Guidelines for the Scheduling of Specific Commitments under the General Agreements on Trade in Services (GATS)', adopted by the Council of Trade in Services on 23 March 2001, S/L/ 92, 28 March 2001.

- (1993), 'Scheduling of Initial Commitments in Trade in Services, Explanatory Note', Note by the Secretariat, MTN.GNS/W/164, 3 September 1993.

- (2003), "Necessity Tests" in the WTO', Note by the Secretariat, Working Party on Domestic Regulation, S/WPDR/W/27, 2 December 2003.

— (2009), 'Draft Disciplines on Domestic Regulation Pursuant to GATS Article VI:4', Second Revision, Informal Note by the Chairman, Room Document, 20 March 2009.

— (2011), 'Disciplines on Domestic Regulation Pursuant to GATS Article VI:4', Chairman's Report Progress, Working Party on Domestic Regulation, S/WPDR/W/45, 14 April 2011. 
(2012a), 'Regulatory Issues in Sectors and Modes and Supply', Note by the Secretariat, Working Party on Domestic Regulation, S/WPDR/W/48, 13 June 2012.

_ (2012b), 'Technical Standards in Services', Note by the Secretariat, Working Party on Domestic Regulation, S/WPDR/W/49, 13 September 2012.

Wouters, J. and D. Coppens (2008), 'GATS and Domestic Regulation: Balancing the Right to Regulate and Trade Liberalization', in K. Alexander and M. Andenas (eds.), The World Trade Organization and Trade in Services, Netherlands: Koninkljke Brill NV, pp. 207-263.

Zdouc, W. (2004), 'WTO Dispute Settlement Practice Relating to the General Agreement on Trade in Services', in F. Ortino and E.-U. Petersmann (eds,), The WTO Dispute Settlement System 19952003, Antwerp: Kluwer Law International, p. 381. 